\title{
THE ACCESSION NARRATIVE \\ (1 SAMUEL 27 - 2 SAMUEL 1)
}

\author{
David G. Firth
}

\begin{abstract}
Summary
This paper offers a reading of 1 Samuel 27 - 2 Samuel 1 as a discrete unit within the books of Samuel which consciously acts as the climax of all that precedes it in 1 Samuel. It is marked by a distinctive narrative style, which shows that it is structurally discrete within the books of Samuel, and yet at the same time it establishes links across the whole of the preceding text. These links enable it to offer a profound reflection on the circumstances and interpretation of Saul's death as well as resolving the question of where David was when Saul died. At the same time, these links transcend the classical source-critical analysis of the books of Samuel, suggesting that the books should be read as a tightlyintegrated whole.
\end{abstract}

\section{Introduction}

Although in recent years it has become a happy hunting ground for more literary approaches to the interpretation of the Old Testament, ${ }^{1}$

1 Prominent examples of this largely English language phenomenon include Keith Bodner, David Observed: A King in the Eves of His Court (Sheffield: Phoenix, 2005), Silvia Becker-Spörl, 'Und Hanna betete und sie sprach ... 'Literarische Untersuchurngen zu 1 Samuel 2:1-10 (Tübingen: Francke, 1992); Walter Brueggemann, Ichcabod Toward Home: The Journey of God's Glory (Grand Rapids: Eerdmans, 2002); Diana V. Edelman, King Saul in the Historiography of Judah (Sheffield: JSOT Press, 1991); Lyle M. Eslinger, Kingship of God in Crisis: A Close Reading of 1 Samuel 1-12 (Sheffield: Almond Press, 1985); Lyle M. Eslinger, House of God or House of David: The Rhetoric of 2 Samuel 7 (Sheffield: Sheffield Academic Press, 1994); J. P. Fokkelman, Narrative Art and Poetry in the Books of Samuel: A Full Interpretation Based on Stylistic and Structural Analyses, Vol I: King David (II Sam. 9-20 \& 1 Kings 1-2) (Assen: van Gorcum, 1981); J. P. Fokkelman, Narrative Art and Poetry in the Books of Samuel: A Full Interpretation Based on Stylistic and Structural Analyses, Vol ll: The Crossing Fates (1 Sam. 13-3, 1 \& II Sam. 1) (Assen: van 
study of the books of Samuel continues to be shaped largely by two hypotheses developed and popularised in the first half of the twentieth century. The first of these was the source-critical analysis developed by L. Rost in which he identified an ark narrative (1 Sam. 4:1b-7:1 and 2 Sam. 6), a History of David's Rise (1 Sam. 16 - 2 Sam. 5) and a Succession Narrative (2 Sam. 9-20) as the principal sources employed in the composition of the books of Samuel. ${ }^{2}$ The other dominant element continues to be Martin Noth's hypothesis of a Deuteronomistic History, ${ }^{3}$ of which the books of Samuel are an integral part. However, in arguing for this, Noth accepted most of Rost's analysis, including his assertion that the Deuteronomist had access to much older materials to which only relatively small adjustments or additions were made. ${ }^{4}$

Subsequent writers have not always accepted this analysis, even where they regard Samuel as part of the Deuteronomistic History. For example, Barbara Green follows Robert Polzin and reads the whole of 1 Samuel as a Deuteronomistic text produced in the exile, ${ }^{5}$ which seeks to vindicate the negative view of kingship that Noth highlighted as one

Gorcum, 1986); J. P. Fokkelman, Narrative Art and Poetry in the Books of Samuel: A Full Interpretation Based on Stylistic and Structural Analyses, Vol III: Throne and City (II Sam 2-8 \& 21-24) (Assen: van Gorcum, 1990); J. P. Fokkelman, Narrative Art and Poetry in the Books of Samuel: A Full Interpretation Based on Stylistic and Structural Analyse, Vol IV: Vow and Desire (1 Sam. 1-12) (Assen: van Gorcum, 1993); Moshe Garsiel, The First Book of Samuel: A Literary Study of Comparative Structures, Analogies and Parallels (Jerusalem: Rubin Mass, 1983); Barbara Green, How Are the Mighty Fallen? A Dialogical Study of King Saul in 1 Samuel (London: Sheffield Academic Press, 2003); Barbara Green, King Saul's Asking (Collegeville: Liturgical Press, 2003); David G. Gunn, The Story of King David: Genre and Interpretation (Sheffield: JSOT Press, 1978); David G. Gunn, The Fate of King Saul: An Interpretation of a Biblical Story (Sheffield: JSOT Press, 1980); David Jobling, The Sense of Biblical Narrative: Structural Analyses in the Hebrew Bible II (Sheffield: JSOT Press, 1986); V. Phillips Long, The Reign and Rejection of King Saul: A Case for Literary and Theological Coherence (Missoula: Scholar's Press, 1989); Peter D. Miscall, 1 Samuel: A Literary Reading (Bloomington: Indiana University Press, 1986); K. L. Noll, The Faces of David (Sheffield: Sheffield Academic Press, 1997); Robert Polzin, Samuel and the Deuteronomist: A Literary Interpretation of the Deuteronomic History, Part Two: I Samuel (Bloomington: University of Indiana Press, 1989); and Robert Polzin, David and the Deuteronomist: A Literary Interpretation of the Deuteronomic History, Part Three: 2 Samuel (Bloomington: University of Indiana Press, 1993).

2 L. Rost, Succession to the Throne of David (Sheffield: Almond Press, 1982): 13-14, 116-120.

3 Martin Noth, The Deuteronomistic History (Sheffield: JSOT Press, 1981).

4 Noth, Deuteronomistic History: 54-57.

5 Green, How are the Mighty Fallen? and King Saul's Asking; Polzin, Samuel and the Deuteronomist and David and the Deuteronomist. 
of the Deuteronomist's central themes. ${ }^{6}$ Nevertheless, these more obviously literary approaches are still shaped by the dominant questions put in place by the theses of Rost and Noth. Others have rejected their scheme altogether, ${ }^{7}$ but it nonetheless remains the dominant model for reading this text.

One of the effects of having a predominant model is that scholarly engagement tends to be focused on those texts most central to the thesis. Hence, there is a massive body of literature on both the Succession Narrative and the most obviously 'Deuteronomistic' components of the books of Samuel in 1 Samuel 12 and 2 Samuel 7, whilst the so-called 'ark narrative' continues to generate a degree of interest. On the other hand, with the obvious exception of Grønbæk, ${ }^{8}$ scholarly interest in the History of David's Rise has been less marked, perhaps because this was always the least well-defined of Rost's sources. The result is that, although some parts of the books of Samuel receive a steady flow of scholarly examination, others are largely bypassed. The danger of this is that it leaves open the possibility that scholarly focus is only directed at those elements that support the dominant hypotheses rather than on those parts of the text that might generate alternative approaches.

The purpose of this article is to explore one section of the books of Samuel where this danger might be highlighted. It is argued that

6 Noth, Deuteronomistic History: 54. More nuanced views of kingship in the Deuteronomistic History, in which the issue is not so much whether kingship itself is viewed negatively (or positively) but rather the issue is the type of king needed, have been argued by Gerald Eddie Gerbrandt, Kingship According to the Deuteronomistic History (Atlanta: Scholar's Press, 1986); and David M. Howard, Jr 'The Case for Kingship in Deuteronomy and the Former Prophets" WTJ 52 (1990): 101-115. See also Marty Alan Michelson, Chaos to Conciliation through Violence in Judges and 1 Samuel, unpublished Ph.D. dissertation, University of Manchester, 2006: 187-214.

7 Note, for example, the somewhat different approach adopted by R. A. Carlson, David the Chosen King: A Traditio-Historical Approach to the Second Book of Samuel (Uppsala: Almqvist \& Wiksells, 1964), who offers a more integrated reading of the whole of 2 Samuel, structured around the themes of 'David under the Blessing' (2 Sam. 2-7) and 'David under the Curse' (2 Sam. 9-24), though still assuming a strongly Deuteronomistic process of formation. An obvious advantage of this approach is that it integrates the so-called Samuel Appendix (2 Sam 21-24) into the whole. See also H. J. Koorevaar, 'De macrostructuur van het boek Samuël en de theologische implicaties daarvan', AcT 17 (1997): 56-86; Herbert H. Klement, II Samuel 21-24: Context, Structure and Meaning in the Samuel Conclusion (Frankfurt am Main: Peter Lang, 2000); David G. Firth, 'Shining the Lamp: The Rhetoric of 2 Samuel 5-24', TynBul 52/2 (2001): 203-224.

8 Jakob Grønbæk Die Geschichte vom Aufstieg Davids (1. Sam. 15 - 2. Sam. 5): Tradition und Komposition (Copenhagen: Prostant apud Munksgaard, 1971). 
1 Samuel 27 - 2 Samuel 1 constitutes an Accession Narrative, an account in which David is finally able to become king. Moreover, it is an integrated narrative, with a number of key features which show its own integrity. But it is also structured as the climax of all that preceded it in 1 Samuel, something that it achieves through a range of intertextual links to what has gone before. It is thus a triumphant account of how David can succeed where Saul fails, but an account that can only be understood against the background of all that has gone before it. The presence of such a text argues against the traditional source divisions whilst also raising questions about the function of the Deuteronomists in the formation of the text. To demonstrate this, it will first be necessary to consider the boundaries of the text and those features which point to its integrity, before considering the intertextual features which link it to the rest of 1 Samuel across the normal source-critical divisions.

\section{Literary Boundaries of the Text}

If this is an integrated narrative which is also the climax of all that has happened so far, it is necessary to demonstrate that it can be identified as a unit of text in its own right. Only once that has been done can we move to consider the ways in which it interacts with the rest of 1 Samuel. Since a number of examinations of the structure of the books of Samuel have offered somewhat different analyses, this becomes an important consideration.

The most detailed studies of the structure of the books of Samuel are offered by Koorevaar ${ }^{9}$ and Klement. ${ }^{10}$ Although Koorevaar's paper was published first, it actually builds upon the work of Klement's doctoral dissertation, which was mildly revised for publication. Both studies are of some importance for us in that they argue for an intentional structure for the whole of the books of Samuel that overrides the traditional source-critical divisions. ${ }^{11}$ Unfortunately, Koorevaar operates only at larger levels of the text, and although he analyses 1 Samuel 15:1 2 Samuel 5:5 as the journey towards David's kingship, ${ }^{12}$ he does not

\footnotetext{
9 Koorevaar, 'Macrostructuur'.

10 Klement, II Samuel 21-24.

11 Koorevaar, 'Macrostructuur', 75, Klement, II Samuel 21-24: 153-59.

12 Koorevaar, 'Macrostructuur': 72.
} 
break his analysis down further, pointing only to the work of Klement. Taken on its own, this segment of Koorevaar's analysis might be thought to represent the History of David's Rise - though since this is part of his argument for an overall chiastic structure for the books of Samuel, it is clear that his concern is with the function of these chapters rather than with their underlying sources.

Klement's analysis also makes extensive use of chiasm as a structuring device in Samuel, ${ }^{13}$ so that his analysis offers an extended series of chiasms rather than one overriding chiasm such as we find with Koorevaar. Building on the work of Robert Gordon, ${ }^{14}$ Klement finds a series of interlinked accounts running from 1 Samuel 25:1-30:31 that are built around the two references to Samuel's death (1 Sam. 25:1; 28:3). From this, a pair of paralleled panels are developed dealing with David sparing Saul (1 Sam. 26:1-25) or not fighting against him (1 Sam. 29:1-11), and David with Achish but fighting Amalekites (1 Sam. 27:1-28:2; 30:1-31). The account of the death of Saul in 1 Samuel 31 can then be shown to be a linked development of Saul's recognition of David's inevitable movement to the throne in 1 Samuel 24. Accordingly, Klement regards 1 Samuel 31 as the end of a major section within the books of Samuel, with 2 Samuel 1-2 effectively a transitional account that prepares for the narrative of David's kingdom. ${ }^{15}$

Although the main lines of Klement's argument are sound, the analysis of this section seems somewhat forced. In particular, although he takes Gordon's work as his starting point, his analysis sets aside Gordon's own observation that 1 Samuel 24-26 constitute a narrative unit in their own right, with the two accounts of David declining to kill Saul interacting with the Nabal narrative. Strictly, Gordon places this set within the slightly larger account of David in the wilderness, which begins at 1 Samuel 23:1416 - though for our purposes the important point to note is the balance between 1 Samuel 24 and 26 and their intertextual relationship with the Nabal story. Certainly, the two accounts of David not killing Saul seem to have a closer structural relationship with one another than allowed by Klement's proposal,

13 Klement, II Samuel 21-24: 86-98.

14 Robert Gordon, 'David's Rise and Saul's Demise: Narrative Analogy in 1 Samuel 24-26', TynBul 31 (1980): 37-64.

15 Klement, II Samuel 21-24: 151-153.

16 Gordon, 'David's Rise': 40. 
which sees no link between them. Indeed, the two accounts are marked by an extensive range of internal parallels, ${ }^{17}$ so that to some extent they constitute variations on a theme. ${ }^{18}$ Given the fondness displayed by the books of Samuel elsewhere for repetition of narratives and narrative themes within the one section of the book, ${ }^{19}$ then it is more likely that we should treat 1 Samuel 24-26 as a complete narrative unit that is concerned with David in the wilderness and which is marked by his two refusals to kill Saul.

More positively, it can be argued that 27:1 represents the beginning of a new section in the narrative in that it initiates the time that David will spend in Philistine territory, living with Achish at Gath before moving to his own town in Ziklag (1 Sam. 27:6). He has, of course, briefly been there before (1 Sam. 21:10-15 [Heb.11-16]) in a visit that establishes his ability to dupe Achish, though at that time Achish proved to be simply one more king from whom he must flee, whereas this time he stays in Philistine territory for sixteen months (1 Sam. 27:7). The change in location, along with the change in role adopted by David, in which he becomes a marauder who raids Israel's enemies whilst claiming to support the Philistines - rather than an outlaw constantly on the run from Saul - marks this as the beginning of a new stage in David's story.

The question of where this story ends, however, is more contentious. Klement's proposal that 2 Samuel 1-2 constitute a unit in their own right, as the record of David's transition to kingship ${ }^{20}$ is odd given that he is already king over Judah by 2 Samuel 2:4, and his conflict with Ishbosheth is not resolved until 2 Samuel 4:12. ${ }^{21}$ Certainly, 2 Samuel 1 is set after the death of Saul and recounts the means by which David received Saul's badges of office (2 Sam. 1:10), but one cannot say that his transition has ended at 2:32. A more common suggestion is that

17 Cf. Ralph W. Klein, 1 Samuel (Waco: Word, 1983): 236-37, though not all of his suggestions are equally persuasive.

18 C. Edenburg, 'How (Not) to Murder a King: Variations on a Theme in 1 Sam. 24; 26', SJOT 12 (1998): 64-85.

19 Cf. David G. Firth, 'Play It Again Sam: The Poetics of Narrative Repetition in 1 Samuel 1-7', TynBul 56/2 (2005): 1-17.

20 Klement, II Samuel 21-24, 151-53.

21 Ronald F. Youngblood, '1, 2 Samuel', in Frank E. Gaebelein, ed., The Expositor's Bible Commentary (Grand Rapids: Zondervan, 1992): 804, offers a not dissimilar analysis, treating 2 Samuel $1: 1-3: 5$ as a section, though on the formal basis that the lists of David's sons in 3:2-5; 5:13-16 and 8:15-18 mark the formal divisions with 2 Samuel 1-8. 
Saul's death in 1 Samuel 31 ends a section of the books, with the next section running from 2 Samuel 1:1-5:10, ${ }^{22}$ with this effectively ending the account of David's rise. The argument in favour of such a reading is twofold. First, it notes that the phrase 'after the death of so-and-so' constitutes a standard mechanism for the beginning of new sections in the Former Prophets, and indeed represents the beginning of the books of Joshua (Josh. 1:1), Judges (Judg. 1:1) and 2 Kings (2 Kgs 1:1). ${ }^{23}$ Second, it recognises the fact that the arrival of the badges of royal office (2 Sam. 1:10) constitutes the point at which David's accession to the throne has formally begun.

These arguments are not of equal value. The use of the formula 'after the death of so-and-so' in each of the passages cited is somewhat different. In Joshua 1:1 and Judges 1:1 it points to a time when an oracle was received from YHWH, an element that is clearly absent here, though it is certainly true to say that these passages represent points where Israel needed to seek new leaders. But the use of the formula in 2 Kings 1:1 has none of these features since it initiates a narrative that describes the events in the northern kingdom of Israel after a Moabite rebellion. Moreover, it is clearly a part of the larger narrative of the house of Omri (1 Kgs 16:21 - 2 Kgs 9:29). The use of the phrase may well have given rise to an interpretative tradition that saw the division of the two books of Samuel at this point, but it does not point to the beginning of a new section here.

That David has now received the badges of office, even though they have not yet been formally recognised, is a more important point. Indeed, recognition of this fact is why we should regard 1 Samuel 27 2 Samuel 1 as the Accession Narrative. It is the account of how David accedes to the throne without committing any violence against Saul, just as he had indicated should happen in 1 Samuel 26:10-11. But it is an account of accession towards the throne, not the formal recognition of it, which will be narrated in 2 Samuel 2:1-5:16. ${ }^{24}$ Throughout

22 See, for example, Bruce C. Birch, 'The First and Second Books of Samuel', in L. G. Keck, ed., The New Interpreter's Bible (Nashville: Abingdon, 1998): 1199. Koorevaar, 'Macrostructuur': 72, is among those who suggest it runs to 2 Samuel 5:5. The precise end of this section need not concern us here, but in line with the argument in Firth, 'Shining the Lamp': 209-14, one could regard 2 Samuel 5:16 as the end of this section. However, the inability of scholars to agree exactly where the History of David's Rise ends might support the larger argument that the current form of the books of Samuel is considerably more than the sum of their parts.

23 E.g. Youngblood, 'Samuel': 804.

24 See above, note 22. 
1 Samuel 27 - 2 Samuel 1, David has remained as a Philistine vassal living in Philistine territory. He will only return to Judah in 2 Samuel 2:1 at which point he will formally become king of Judah, and ultimately of Israel and Judah (2 Sam. 5:1-5). The geographical boundaries alone are enough to suggest that 1 Samuel $27-2$ Samuel 1 constitutes a discrete section within the books of Samuel. ${ }^{25}$

\section{Key Literary Features}

The case for the integrity of 1 Samuel $27-2$ Samuel 1 can be strengthened by consideration of some of its key literary features, all of which demonstrate a number of highly skilled compositional techniques, some of which are not seen elsewhere in the books of Samuel. The key elements for us to note are hypotactic narration, a tiled coupled plot, and the use of narrative repetition. These features provide additional reasons for treating this as a discrete section of the books of Samuel.

\subsection{Hypotactic Narration}

Readers arriving from the earlier parts of 1 Samuel may note that there is a shift in the style of narration that is employed from 1 Samuel 27 and which will be set aside after David's lament in 2 Samuel 1. Apart from the account of the travels of the ark in Philistine territory and its ultimate return to Judah in 1 Samuel 5:1-7:1, and the account of Absalom's rebellion (2 Samuel 13-19), the books of Samuel primarily employ a form of paratactic narrative. ${ }^{26}$ Paratactic narration occurs when the logical and temporal links between different narratives are unexpressed, and the narratives are essentially juxtaposed to one another. By contrast, in hypotactic narration the logical and temporal links are made explicit so that readers are able to see the nature of the links. To some extent, it is probably better to say that narratives tend

25 Although they do not provide an argument in support of such an analysis, the divisions offered by Green, How are the Mighty Fallen: 411-46, and Fokkelman, Crossing Fates: 555-682 (esp. 555-57) agree with the position argued here.

26 The same phenomenon is sometimes described as serial and episodic narration, though these categories are occasionally blurred into one another. Cf. Jean Louis Ska, Our Fathers Have Told Us: Introduction to the Analysis of Hebrew Narratives (Rome: Pontifical Biblical Institute, 1990): 12, and literature cited there. See also the examples cited by Robert Alter, The Art of Biblical Narrative (New York: Basic Books, 1980): $131-54$ 
toward being hypotactic or paratactic as the distinction is seldom absolute, but the general trend certainly holds.

Although we cannot explore this in detail throughout the books of Samuel, it is certainly clear that 1 Samuel 24-26 represents a collection of paratactic narratives. Each of these stands complete in itself, with its own plot being completely resolved internally. Thus, in 1 Samuel 24, David was confronted with the opportunity to kill Saul whilst hiding in a cave with his men, and indeed was urged by them to do so (1 Sam. 24:4 [Heb. 5]). Instead, David cut off the corner of Saul's robe, and was then struck by his heart ${ }^{27}$ so that he presented himself to Saul. After an extended dialogue, Saul finally confessed that David was the more righteous and would surely become king (1 Sam. 24:17-20 [Heb. 18-21]). After swearing oaths, David and Saul separate from one another. A similar structure occurs in 1 Samuel 26, except that this time David initiated the contact with Saul, but their separation also marks the end of the narrative. The Nabal story (1 Sam. 25) is also complete in itself, recounting how David was prepared to kill Nabal but was prevented from doing so by YHWH through the intervention of Abigail. Each narrative is complete in itself, but the interrelationship which exists between them is a result of their juxtaposition, not the presence of logical or temporal indicators. Similarly, each of the three accounts in 2 Samuel 2:1-3:1 - David's coronation in Judah (2 Sam. 2:1-8), Ishbosheth's coronation (2 Sam. 2:9-11), and the conflict between the ruling houses (2 Sam. 2:12-3:1) - is a self-contained narrative, which gains its meaning through its juxtaposition to the narratives around it rather than through direct links.

By way of contrast, 1 Samuel 27 - 2 Samuel 1 represents a hypotactic narrative in which the various elements are specifically joined to the elements that have gone before by means of logical and (especially) temporal markers. As is typical of Hebrew narrative generally, each new narrative element within these chapters is introduced by means of a waw-consecutive. A number of English translations give the impression of a logical link between 1 Samuel 27:1 and what has gone before, ${ }^{28}$ but though this is no doubt necessary for English style it could create a misleading impression, since the use of the waw-consecutive at

27 Surely an expression of a sense of guilt, and not the palpitations that Fokkelman, Crossing Fates: 455 suggests. The more important point is the way this sets up the use of 'heart' as a Leitwort through chapters 24-25.

28 E.g. ESV. 
1 Samuel 27:1 is effectively the same as that which occurs at each of 1 Samuel 24:1, 25:1 and 26:1.29 Although the opening clause of

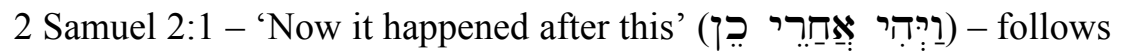
logically from the whole of 1 Samuel 27 - 2 Samuel 1, it will be noted that it breaks the temporal links carefully woven though the whole of the Accession Narrative. Although there is a broad development in the accounts that follow, the links between them are paratactic.

The importance of the temporal links through the Accession Narrative can be seen in the chart of parallel events developed by Fokkelman, ${ }^{30}$ though it should be noted that it takes great care to establish a range of temporal markers throughout. Thus, we are told that David spent one year and four months in Philistine territory (1 Sam. 27:7), ${ }^{31}$ time that was in effect preparation for the battle in which Saul would die. Achish's speech to the other Philistine rulers in 1 Samuel 29:3 makes this link clear, as it refers back to this marker as the justification for permitting David to remain in the Philistine army. In addition, there is a cluster of references to the third day in 1 Samuel 30 and 2 Samuel 1 (1 Sam. 30:1, 12, 13; 2 Sam 1:2), all of which tie the events of David's time in the south to the events that were unfolding in the north. Indeed, apart from 1 Samuel 27, which functions as an introduction to David's time in Philistine territory, the whole of the Accession Narrative is focused on the events which would unravel on Mount Gilboa. Although it contains a range of elements, there is a single plot line. This does not mean that the whole of the account is narrated in its exact chronological sequence. Saul's visit to the spirit mistress at Endor (1 Sam. 28:3-25) must have taken place after David had been dismissed from the Philistine camp (1 Sam. 29:11) and returned to

29 One should not make too much of $25: 1$, since the note of Samuel's death is set aside for the following narrative, though it is certainly there to create an important background to it.

30 Fokkelman, Crossing Fates: 594. Unfortunately, an otherwise clear chart is obscured by Fokkelman's decision to randomly assign 4 May as the starting date for the various events rather than simply list each point as 'Day 1' and so on. See also the similar chart in Robert D. Bergen, 1, 2 Samuel (Nashville: Broadman, 1996): 285. Bergen's structure is preferable in some ways, but lacks some of Fokkelman's detail.

31 The text has some problems, but S. R. Driver, Notes on the Hebrew Text and Topography of the Books of Samuel (Oxford: Clarendon , 1913): 163 has established that ירימִים (commonly 'days') can have the sense of 'year'. This suggests that LXX's omission of a difficult word was probably an attempted correction of a difficult text rather than evidence for a different Vorlage as previously supposed by Henry Preserved Smith, A Critical and Exegetical Commentary on the Books of Samuel (Edinburgh: T \& T Clark, 1899): 236. 
Ziklag, ${ }^{32}$ but the point is that apart from the introductory account of David with the Philistines in 1 Samuel 27, each new narrative segment is related to Saul's death. If one of the key concerns of this narrative is to explain why David was not involved in Saul's death, ${ }^{33}$ then this is what we would expect, and a hypotactic narration is thus essential to make the point.

\subsection{Tiled Coupled Plot}

Some of the elements to be considered here follow on directly from the fact that the Accession Narrative employs hypotactic narration. We have a single plot line which can be traced through, explaining why David was not involved in Saul's death but received Saul's badges of office anyway. David's earlier refusal to take matters into his own hands (1 Sam. 24; 26) is thus vindicated. Because the narrative needs to cover this plot properly, it needs to couple two sub-plots to demonstrate this, following the experiences of both Saul and David.

Saul's story is told in two blocks, starting with his encounter with the spirit mistress at Endor (1 Sam. 28:3-25) - an account that ends with the prediction of his death the following day, a prediction that is delivered through Samuel's shade whom the woman apparently summons for Saul (1 Sam. 28:16-19). Apart from Saul's death, which was to happen the following day, his sons would die with him and YHWH would hand the kingdom over to David. Saul's meeting with the spirit mistress is concluded with a meal that she prepares for him before he returns to the Israelite camp. The second block concerned with Saul is the first account of his death in 1 Samuel 31, an account in which Saul dies by committing suicide (1 Sam. 31:4).

32 This is clear from the location of the Philistine army at the various points mentioned. At 1 Sam. 28:5, they are already at Shunem, close to Gilboa in the Jezreel valley. But when David was dismissed before the battle, they were only at Aphek (1 Sam. 29:1), which is south east of Shunem. The Philistine forces were journeying north throughout, so David had to have been dismissed before Saul's visit to Endor. Other narrative concerns have led to this arrangement of the text. See below, section 3.2 on the tiled coupled plot.

33 Steven L. Mckenzie, King David: A Biography (New York: OUP, 2000): 101-10, and Baruch Halpern, David's Secret Demons: Messiah, Murderer, Traitor, King (Grand Rapids: Eerdmans, 2001): 78-81; both argue that this was the central concern, though in fact neither believes the alibi to be truthful. One does not have to be so sceptical of the claim of the narrative simply because it has an apologetic purpose since evidence of innocence needs to be produced where an accusation is made. For a contrasting view, cf. Iain Provan, V. Phillips Long and Tremper Longman III, A Biblical History of Israel (Louisville: Westminster John Knox, 2003): 215-27. 
David's story is told in three blocks, in 1 Samuel 27:1-28:2, 29:130:30 and 2 Samuel 1:1-27. In 1 Samuel 27:1-28:2, we have the second account of David fleeing to Achish and duping him, though this time with the result that he is brought into the Philistine army when they go forth to battle Saul. In 1 Samuel 29-30, David is ejected from the Philistine army by those who remember his previous exploits (1 Sam. 29:4-5) before returning to Ziklag (1 Sam. 30:1). Upon his return, he discovers that the Amalekites whom he has been raiding have raided him, so that he has to lead his men out into the Negeb to recover their wives and possessions at the same time as Saul was facing defeat from the Philistines. Finally, in 2 Samuel 1, David hears the second account of Saul's death, to which he responds by executing the Amalekite who claimed to have killed Saul and then expresses himself in a lament over Saul and Jonathan.

These two plot lines are tiled, that is, they are laid over each other so that the narrative segments overlay each other, like tiles on a roof. ${ }^{34}$ It is the temporal and logical markers that run through the narrative that allows this to happen. These markers are scattered, but along with the plot are consistently focused on the battle that leads to Saul's death. Thus, at the end of the initial account of David's time with Achish, we are told that 'In those days the Philistines assembled for battle' (1 Sam. 28:1). Although this assembly must have been within Philistine territory, this is linked to the fact that Saul sought guidance from the spirit mistress when he saw the same force encamped at Shunem (1 Sam. 28:4-7). After Saul's encounter with the spirit mistress, the narrative backtracks to describe David's ejection from the Philistine forces whilst they were at Aphek (1 Sam. 29), and then his experiences in Ziklag after his return. The various references to the 'third day' (1 Sam. 30:1, 12, 13) make clear that while David was being evicted from the Philistine camp, the Amalekites were raiding Ziklag - though this raid is not described because it would detract from the central plot focus. These temporal details make it very clear that although David was notionally working for the Philistines, he was actually as far away as possible from Saul at the time of his death because the events of chapters 30 and 31 are happening simultaneously. The visit by the Amalekite who gives David his report of Saul's death is also tied into this structure since he too arrives on the third day after David's return

34 Ska, Our Fathers Have Told Us: 10-11. 
to Ziklag (2 Sam. 1:2), which is also the time that is needed to travel from Gilboa to David.

The adoption of such a narrative structure also requires mechanisms to sustain the interest of those who hear and read. ${ }^{35}$ The tiling and coupling need to retain interest in the main plot, but must also do so with those plot elements that were coupled to achieve the main plot. This is brought about through the deliberate non-resolution of sub-plot items that are not addressed again until the coupled plot is also advanced. In terms of the modern soap-opera, there is a collection of 'cliff-hangers' to sustain interest. Thus, after David has successfully duped Achish into thinking he is raiding Judean territory when in reality it was the Amalekites, his own duplicity seems to bounce back on him when Achish informs him that he will not only be required to go to battle with him against Israel, but also that he shall be his bodyguard (1 Sam. 28:1-2). David is in a seemingly impossible situation, but this element of the narrative is left aside until Saul's encounter with the spirit mistress is resolved (1 Sam. 28:3-25). After Samuel's announcement to Saul there (1 Sam. 28:16-19), he too appears to be in an impossible situation since it is clear that YHWH is against him. It is the need to create a seemingly impossible situation for both protagonists that leads to the present arrangement of the material, even though David was in fact released from the Philistine forces before the events at Endor. ${ }^{36}$ The coupling of the plot lines is thus an essential element in narration, since only with this done could the necessary synchronisms be achieved whilst also generating interest in the extended narration.

\subsection{Narrative Repetition}

A final element that is particularly evident in the Accession Narrative is the use of narrative repetition, in which certain themes are introduced

\footnotetext{
35 On the use of suspense in biblical narrative, see Meir Sternberg, The Poetics of Biblical Narrative: Ideological Literature and the Drama of Reading (Bloomington: Indiana University Press, 1987): 264-68.

36 This alone makes the view of Michael Kleiner, Saul in Endor, Wahrsagung oder Tötenbeschwörung? Eine Synchrone und Diachrone Untersuchung zu 1 Samuel 28, (Leipzig: Benno, 1995): 7, that the arrangement of the material rips the narrative structure apart improbable. The books of Samuel make frequent use of dischronologised narrative, a feature also evident in 1 Samuel 16-17. Cf. David G. Firth, "That the World Might Know": Narrative Poetics in 1 Samuel 16-17', in Michael Parsons ed., Text and Context: Scripture and Mission (Milton Keynes: Paternoster, 2005): 20-32.
} 
and then repeated in paralleled accounts. ${ }^{37}$ Repetition of key themes is a common element within the books of Samuel, ${ }^{38}$ yet even when this is taken into account, the extent of repetition in this section is still noteworthy, though generated by the hypotactic narration and tiled coupled plot. Thus, as noted already, there are two introductory accounts that set out the problems for David (1 Sam. 27:1-28:2) and Saul (1 Sam. 28:3-25). There also two accounts of David's activities at this time (1 Sam. 29:1-11; 30:1-31), two accounts of Saul's death (1 Sam. 31; 2 Sam 1:1-10), and finally, two responses by David to the news of Saul's death as it is reported to him (2 Sam. 1:11-16, 1:17-27). Although each doubled narrative contributes to its own plot line, it also contributes to the overall plot. Moreover, the fact that the second response to the deaths of Saul and Jonathan is cast in the form of a poem immediately marks this section as significant. When everything else comes in pairs, a sole poem, even if it is the second response to the news about Saul and Jonathan, is structurally highlighted. Indeed, poems are a crucial tool used by the authors of the books of Samuel to guide readers as to the interpretation of their narratives. Hannah's song (1 Sam. 2:1-10) is placed so as to generate the key themes for all that will follow, especially with its reference to the coming of kingship (1 Sam. 2:10). In the so-called 'Samuel Appendix', we find two songs attributed to David (2 Sam. 22:2-51; 23:1-7), both of which meditate on what it is to be successful as a king. Here, at the end of the reign of Saul, a poem is provided which reflects on the life of Israel's first king. ${ }^{39}$ Hence, the narrative devices employed in the Accession Narrative are structured to bring readers to David's lament, and then to highlight the lament so that its themes cast light on all that has gone before. As we shall see, that light is not just over the Accession Narrative, but over all that has preceded it in the books of Samuel.

37 On the various forms of repetition and their functions, see Sternberg, Poetics: $365-$ 440.

38 Cf. David G. Firth, 'Parallelismus Membrorum in Prose Narrative: The Function of Repetition in 1 Samuel 5-6', OTE 15/2 (2002): 647-56, and 'Play It Again Sam: The Poetics of Narrative Repetition in 1 Samuel 1-7', TynBul 56/2 (2005): 1-18.

39 On the structural significance of these songs and their placement, see Fokkelman, Crossing Fates: 105-07, and Klement, II Samuel 21-24: 111-17. 


\section{Intertextual Themes}

The structure and form of the Accession Narrative can thus be recognised as bringing a close to the reign of Saul and preparing the way for David's coronation. However, the larger claim here is that this narrative is intended to operate as the climax of all that preceded it in 1 Samuel. This is achieved through a range of intertextual references that point back to earlier narratives, and which operate at both the thematic and incidental levels. From this, it will become evident that the Accession Narrative is aware of a wide range of traditions that call into question both the traditional source-critical analyses of the books of Samuel and the place of the Deuteronomists as the final redactors. Although there are a number of allusions that we can trace within the traditional boundaries of the History of David's Rise, we shall concern ourselves only with three themes: allusions to Amalek and therefore to Saul's loss of the kingdom; allusions to Eli; and the links between David's lament over Saul and Jonathan with Hannah's song and the two songs in 2 Samuel 22:2-23:7. The importance of these three is that they transcend the main source analyses of the books of Samuel and show the links between the Accession Narrative and the whole of the books of Samuel

\subsection{Amalek and Saul's Loss of the Kingdom}

As is well known, Saul loses the kingdom in two stages. The first occurs when he wrongly offers a sacrifice instead of waiting for Samuel in 1 Samuel 13:8-15. At this point, Saul's family loses the opportunity to establish a dynasty, but the throne itself is not removed. ${ }^{40}$ More decisively, in 1 Samuel 15, Saul was charged with carrying out the 'ban' (חִֶ? (ח) on Amalek in recognition of their attack on Israel described in Exodus 17:8-16. Although he initially claimed to have been faithful to the command of YHWH (1 Sam. 15:13), the narrator has already made clear in verse 9 that Saul had kept back the

40 The exact nature of Saul's sin here is disputed, but, with Long, Reign and Rejection: 43-66, it is important to see a range of literary patterning with 1 Samuel 10, where Saul failed to attack a Philistine outpost (1 Sam. 10:7) as was required. Cf. A. H. van Zyl, 1 Samuël (2 vols) (Nijkerk: G. F. Callenbach BV 1988, 1989): 1:169. It seems that Saul's failure is that he repeatedly fails to do that with which he was charged. Such patterns render improbable the view which argues that Saul was simply fated to failure (e.g. Steven L. McKenzie, 'Saul in the Deuteronomistic History', in Carl S. Ehrlich and Marsha C. White, eds, Saul in Story and Tradition (Tübingen: Mohr Siebeck, 2006): 62). 
best of the livestock, only carrying out the ban on the worthless livestock. As a result of this, Samuel makes his famous speech in which he insists that obedience is better than sacrifice, before equating rebellion with divination (1 Sam. 15:22-23). In spite of Saul's ultimate confession of $\sin$ (1 Sam. 15:24-25), Samuel announces that YHWH had rejected Saul as king, and given the kingdom to his neighbour (1 Sam. 15:26-28). ${ }^{41}$ The exact provenance of 1 Samuel 15 is disputed, ${ }^{42}$ but it appears to have some well-established Deuteronomistic themes although it is best to think of Deuteronomistic editing rather than this being something cut from a whole cloth. ${ }^{43}$ Seen in this light, it is possible to see the whole of 1 Samuel $13-15$ as a block of text recording a two-stage rejection of Saul rather than a patchwork of pieces, even if it was edited into its current form. ${ }^{44}$

For our purposes, the crucial point to note is the extensive level of allusion to these events that runs through the whole of the Accession Narrative - much more than the association with 28:17-19 than is typically noticed. ${ }^{45}$ Of particular importance is the fact that Saul's failure to devote Amalek to destruction in 1 Samuel 15 was the trigger that led to his rejection as king. After 1 Samuel 15, Amalek is not mentioned again until the Accession Narrative, in which there is a sudden block of references to them. In each case, David is the one who acts as Saul did not. That is to say, David is the king in waiting, and he acts towards Amalek as was expected, even if he was not formally practising the ban.

41 Peter Mommer, Samuel: Geschichte und Überlieferung (Neukirchen-Vluyn: Neukirchener Verlag, 1991): 135, follows the tradition of bracketing 1 Sam. 13:7-15 as a later insertion to 1 Samuel 13, so that there is only one rejection. But this approach fails to attend to the ways in which repetition is employed in the books of Samuel, and misses the links to 1 Samuel 10.

42 See the summary in Klein, 1 Samuel: 147-48, though the presence of such Deuteronomistic themes as the ban is to be noted. Grønbaek, Die Geschichte vom Aufstieg Davids, is almost a lone voice in claiming that this is the beginning of the History of David's Rise.

43 So Noth, Deuteronomistic History: 55.

44 Similarly, Long, Reign and Rejection, 166-69. Cf. Bruce C. Birch, The Rise of the Israelite Monarchy The Growth and Development of 1 Samuel 7-15 (Missoula: Scholar's Press, 1976): 105-06.

45 The extent of these allusions, and the lack of explicitly Deuteronomistic vocabulary, argues against the attempt of Fabrizio Foresti, The Rejection of Saul in the Perspective of the Deuteronomistic School (Rome: Edizioni del Teresanum, 1984): 133-36, to find extensive Deuteronomistic editing of 1 Samuel 28:3-25. 
Evidence for this is introduced as early as 1 Samuel 27:8, where we are told that David was 'raiding' (פָּ group of other peoples associated with the Negeb, although David told Achish that he was raiding Judah. After David's ejection from the Philistine camp, he returned to Ziklag to discover that the Amalekites had raided the town, though unlike David they had carried off the survivors, presumably to sell as slaves (1 Sam. 30:1-2). David therefore had to go further into the wilderness to pursue these groups, and was able to overtake them as promised by YHWH (1 Sam. 30:7-8). Once he found them, he was able to attack at first light the following day, ${ }^{46}$ killing all but four hundred who fled on camels. The importance of this becomes more apparent when we consider the effect of the coupling of the narratives of Saul and David and the temporal markers that are provided, because these suggest that David was defeating the Amalekites at precisely the same time as Saul was being defeated by the Philistines. ${ }^{47}$ The timing is surely meant to be significant and laced with irony. Saul had finally lost the throne because of his failure to deal appropriately with Amalek. Saul was also meant to deliver Israel from the hand of the Philistines (1 Sam. 9:16). Yet at the point at which Saul was being defeated by the Philistines and ultimately taking his own life (1 Sam. 31), David was defeating Amalek, which would ultimately lead him to the throne and his own defeat of the Philistines (2 Sam. 5:1725). The final irony, of course, is that it is an Amalekite who reports Saul's death to David, even if his report is shaped more by personal concerns than faithfulness to what took place. ${ }^{48}$ The repeated references to Amalekites in the account surrounding Saul's death thus provide an important allusion to 1 Samuel 15, and from it back to the events of

46 The translation of 1 Sam. 30:17 is disputed, though the parallels adduced by $D C H$

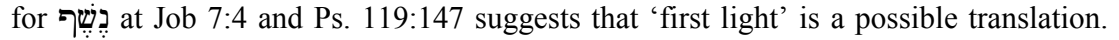
See also Nina L. Collins, 'The Start of the Pre-Exilic Calendar Day of David and the Amalekites: A Note on 1 Samuel xxx 17', VT 41 (1991): 203-10.

47 So also Fokkelman, Crossing Fates: 595.

48 Bill T. Arnold, 'The Amalekite's Report of Saul's Death: Political Intrigue or Incompatible Sources?' JETS 32 (1989): 289-98, has shown that there is more compatibility between the reports than often supposed, contrary to the view of John Mauchline, 1 and 2 Samuel (London: Marshall, Morgan and Scott, 1971): 197, who accepts the presence of different sources and for whom the report of the Amalekite 'rings true'. Cf. Smith, Samuel: 251. Similarly, the type of harmonisation offered by Bergen, Samuel: 288 (following Josephus, Antiquities, 6: 370-72) is rendered unnecessary by the fact that the account in 1 Samuel 31 is offered by an extradiegetic narrator. 
Saul's accession and rejection. The moment of Saul's death is saturated with allusions to his earlier failure.

But allusion back to 1 Samuel 15 is not limited to the references to the Amalekites. There is another important allusion in 1 Samuel 28:17$19,{ }^{49}$ where Samuel's question to Saul explicitly links this passage with 1 Samuel 15:28. But there are other verbal links that run throughout the account at Endor, the most notable of which is the use of the verb 'to divine' (קָ statement in 15:23 that rebellion was like 'divination'. Samuel's shade was recognised by Saul from the spirit mistress' description when she refers to him wearing a 'robe' (מְצִיל), a term for clothing that is only used for the outer garment of someone of rank in the books of Samuel, and which is a constant in the characterisation of Samuel across the book. Reference to Samuel's robe here alludes back to the garment torn by Saul in 1 Samuel 15:27, which in turn alludes back to the garment that Hannah would bring Samuel each year (1 Sam. 2:19). This cluster of terms once again points back to Saul's great moment of failure, offering a reflection on the events that surrounded his death, and suggesting the reasons for his coming fall.

\subsection{Parallels with Eli and his Sons}

Although the links between the Accession Narrative and 1 Samuel 15 are most obvious, there are a range of smaller parallels which are drawn. As a sample of these, we can consider the links between the deaths of Saul and Eli. Two parallels between them appear to be made by the narrative. The first of these is that in both cases the father and his sons die on the one day as a result of battle with the Philistines (1 Sam. 4:11-18; 31:1-6). ${ }^{50}$ Such a parallel might appear to be slight and nothing more than the use of a type-story ${ }^{51}$ if it were not for a number of subsidiary features. In both cases, the sons are said to be killed by the Philistines (1 Sam. 4:11;31:2), but although both fathers die as a result of the battle, neither is killed by the Philistines, with Eli

49 Fokkelman, Crossing Fates: 610, is probably correct to note a link to $13: 11-12$ in the form of Samuel's question in 28:15, strengthening the links across these chapters. Likewise, his desire to receive specific guidance at this point shows close parallels to 1 Samuel 14.

50 Saul's son Ishvi (1 Sam. 14:49) is not mentioned in 1 Sam. 31:2. Presumably, he is to be identified with Ishbosheth, his absence thus preparing for the conflict between him and David in 2 Samuel 2-4.

51 Alter, Art of Biblical Narrative: 47-62. 


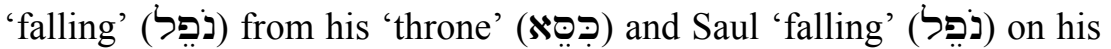
sword. Moreover, both die after an oracle which has announced coming death. In Eli's case, there are two such oracles (2:27-36, 3:10-14), whilst for Saul there is only one (28:16-19). It is striking that one is Samuel's first oracle (to Eli), and one is his last (to Saul).

Eli's death, of course, was not specifically foretold, though it is closely linked to the events surrounding the death of his sons and the capture of the ark of the covenant. But there is a second link, which is that Saul's relics are sent to a Philistine temple (1 Sam. 31:9) while

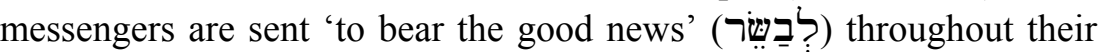
territory. When the ark was captured a messenger came to Eli who is described by the same root (1 Sam. 4:17), even though its use in a context of defeat is striking since elsewhere it refers to good news. What is striking and odd in the experience of Eli is reality in the case of Saul, a point on which David will pick up in his lament (2 Sam. 1:20). There is thus a cluster of allusions back to Eli in the account of Saul's death, a cluster that points to YHWH's judgement on him, just as it had been on Eli and his house. In closing, we should also note that Saul's relics were recovered for him by the men of Jabesh Gilead (1 Sam. 31:11-13), so that reference to them becomes the bookends of Saul's kingship (1 Sam. 11:1-11).

\subsection{David's Lament and the Songs of Samuel}

As noted above, David's lament over Saul and Jonathan functions as the climax of the Accession Narrative, as well as drawing the first period of kingship in Israel to a close. The lament itself contains a number of references to the experiences of Saul and Jonathan, and appears to provide a number of parallels that could be explored. ${ }^{52}$ However, we shall restrict ourselves to one point only: the way in

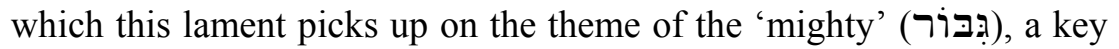
term in Hannah's song which will also be prominent in David's two songs in 2 Samuel 22:2-23:7.

Hannah's song celebrates the fact that YHWH brings about a rever-

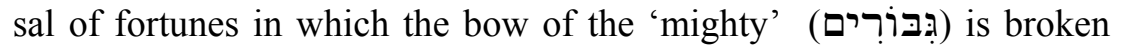

52 A moving treatment of the lament that is aware of many of these, but shaped by the author's own sense of loss following the tragic death of his friend (and my doctoral supervisor) W. S. Prinsloo, is given by A. H. van Zyl, 'Jy was baie na aan my hart (2 Sam. 1:26)', SK 19 (1998): 664-75. Perhaps tragedy is the best way to experience this lament. 
(1 Sam. 2:4). Three times in his lament, David refers to this reversal of fortunes through the refrain 'How the mighty (בְּבֹֹּרִים) have fallen'. In addition, the lament makes extensive reference to various weapons (2 Sam. 1:21-22) before concluding with the statement that 'The weapons of war have perished. ${ }^{53}$ Israel has sought a king of her own choosing, and in doing so has found one who is mighty. But the process has brought profound pain and grief. Yet Hannah's song had also looked towards the coming of a king (1 Sam. 2:10), and the fact that David is now the only anointed of YHWH left leaves hope for the nation.

The keyword (רפבּ, 'mighty one') is picked up in both of David's closing songs, but in neither case is the sense of 'might' accentuated. In 2 Samuel 22:26, David reflects upon the mercy he has received from

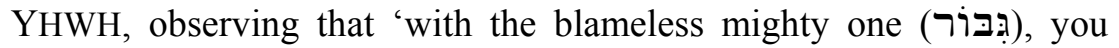
(YHWH) show yourself blameless'. Hope for the king in this instance is not in might, but in the grace of YHWH. Similarly, in his 'last words', David describes himself as 'the mighty one (גֶֶר ) raised high' (2 Sam. 23:1) with the clear implication that he has been exalted by YHWH. According to these songs, David has learned the lesson that kings have to reign by understanding that authority belongs to YHWH. David's lament over Saul and Jonathan thus simultaneously closes off the first account of kingship in Israel by looking back to Hannah's song, whilst preparing for the account of his own reign by planting allusions to be picked up again in his later songs. Thus, we have the climax of the first part of Samuel, and the introduction that prepares us for the next.

\section{Conclusion}

The Accession Narrative emerges from this study as a crucial element in the study of the books of Samuel. It is a highly polished piece of literature with developed literary features that do not only seek to resolve the question of where David was when Saul died: in addition, it offers a profound theological reflection on Saul's death through a range of allusions to earlier parts of the books of Samuel, whilst also setting

53 It is unlikely that 'the weapons of war' is a direct reference to Saul and Jonathan, though with Robert Alter, The David Story (New York: Norton, 1999): 201, we understand by metonymy that there is still an allusion to those who wielded them. 
the stage for what follows. The range of allusions found within it transcends the traditional source analyses, suggesting that the books of Samuel are a more tightly integrated piece than some have argued although this integration is not necessarily Deuteronomistic. ${ }^{54}$ The Accession Narrative should not be looked at in source-critical terms since it is so closely integrated to its context. Rather, it needs to be recognised as a supreme literary achievement that it is a demonstration of what could be achieved through the subtlety of well-told narrative. In turn, that such narrative subtlety exists in a narrative that refers to elements across the whole of $1-2$ Samuel, acting as the climax of the account of Saul whilst preparing for the reign of David, suggests not only that more integrative readings of the text are needed, but also that some of the fundamental issues of sources and redaction may need to be reconsidered.

54 Antony F. Campbell, Of Prophets and Kings: A Late Ninth-Century Document (1 Samuel l - 2 Kings 10) (Washington: Catholic Biblical Association, 1986): 70-71, includes the whole of the Accession Narrative in his ninth-century prophetic record, though includes it as part of the History of David's Rise. If this date can be verified, then given the probable allusions back to Deuteronomistic material, one is forced to take an earlier date for Deuteronomy than the seventh-century one commonly given. 